\title{
Analyzing the Consequences of Bad Outsourcing on Human Resources in Iranian Public Organizations
}

\author{
Ali Asghar Pourezzat ${ }^{1}$, Elham Heydari ${ }^{1},{ }^{*}$ Nader Seyed Kalali ${ }^{1}$, Ghazaleh Taheri Attar ${ }^{2}$ \\ ${ }^{1}$ University of Tehran, Iran \\ ${ }^{2}$ Allameh Tabatabai University, Iran \\ *Nader_Kalali@ut.ac.ir
}

\begin{abstract}
The purpose of present research is to compare the status of perceptional and behavioral consequences on employees who serve in bad-outsourced departments of one of Iranian public organizations and the status of consequences on those employees who serve in non-outsourced departments of the same organization. In this line, such variables as organizational justice, organizational commitment, organizational identity, job security and anti-citizenship behaviors are compared between two groups of staff. The findings show that the rate of organizational justice, organizational commitment, organizational identity and job security among those employees who serve in bad-outsourced sectors is lower than similar variables among non-outsourced ones. In the meantime, there is no significant difference between groups in terms of anticitizenship behaviors variable. Noteworthy, present study was conducted in summer and fall 2010 in Iran.
\end{abstract}

Keywords: Bad Outsourcing, Organizational Justice, Organizational Commitment, Organizational Identity, Job Security and Anti-citizenship behaviors

\section{Introduction}

It is a long time that outsourcing has been considered as a solution to remove old bureaucratic dysfunctions by administrative theorists while it has caused new dysfunctions. The biggest problem in this arena is nonsuccessfulness of governments in fair outsourcing, so that in many cases, national resources and facilities are assigned to private sector too cheaply. The result is irrevocable damages to wealth distribution. Due to assigning some exclusive advantages, new dealers have been emerged between work force and government. They have founded a modern slavery to decrease the costs and to increase their profits, so that in new system, workers never enjoy job security and have to do anything to survive. Thus, the preliminary aims of outsourcing such as competition development in the market, job creation, cost mitigation and productivity increase will be never achieved and a part of services already provided by government in lower costs is assigned to private sector to be delivered with higher prices and costs! Denhardt believes that government is not responsible to row, since providing services by governments is in contradictory to optimization and productivity principles. He also states that government is not responsible for steering since citizens should achieve a level of maturity to play the role of a leader (Denhardt, 1999). Therefore, Denhardt emphasizes that a major part of government's time should be allotted to build the boat (Denhardt, 1999), But In the current method of privatization in Iran, the government does not row, does not steer and does not build the boat; actually, they lend the boat!

In fact, government is not an intelligent seller; and does not choose the suitable alternative in terms of cost and benefit. In recent years, a part of public services along with relevant employees is assigned to contractors. These contractors look for more profit without any responsibility and accountability. If continues, it would pose irrevocable damages on domestic administrative structure and its work force. Hence, maybe the only method to entrust the productivity of new emerging Iranian contractors is to control and monitor their performance. The negative effects of this kind of outsourcing are too many to go into, but, to name a few, researchers in the present study, try to investigate the consequences of "Bad Outsourcing" on perceptions and behaviors of employees. Organizational justice, organizational commitment, organizational identity and job security as perceptional outcomes and organizational anti-citizenship behaviors as the behavioral consequences of "Iranian Style Outsourcing" are studied variables in present research. So, the major question 
of the research is as follows: What is the difference between the status of perceptions and behaviors of employees in those organizations that have outsourced a part of their processes improperly, and the status of perceptions and behaviors of employees in those organizations that are performing their processes traditionally?

\section{Literature Review}

Today, outsourcing is considered as powerful mechanism to mitigate the costs and to improve the performance (Marshall et al, 2007). Belcourt (2006) believes that outsourcing is the best solution when an organization needs experts but it cannot employ or train them. Many organizations are looking for financial saves, hiring experts or technologies; so they outsource part of their processes. Consequently, some believe that outsourcing is a way to keep or increase organizational advantages; and some consider it as one of the main causes of employees' job insecurity (Weidenbaum, 2005). In past, organizations apparently outsourced their side activities; today, we are observing an increase in outsourcing scale. Nowadays, organizations outsource any process from technology management to HR management (Belcourt, 2006). The diversity of outsourcing definitions indicates that it is not a simple process to be easily executed by organizations to achieve their goals. Perhaps, it is for the same reason that outsourcing is highly considered by researchers (Wendell, 2009). Various definitions are provided for outsourcing including outsourcing means contractual relations to provide business services by foreign suppliers; outsourcing happens when organization contracts a foreign contractor and it commits to deliver a certain service and/or product to the organization (Belcourt, 2006).

Those organizations that have outsourced their processes due to follow a fashion, have encountered unanticipated and complicated costs. Many contractors have faced with financial problems or are taken over by other organizations with different procedures and priorities. Those businesses, which try outsourcing blindly, would fail (Weidenbaum, 2005). The inflexibility of contracts is another major problem of outsourcing. Contracts should change based on new needs and conditions. However, contracts are not adaptable and are inflexible (Brandes et al, 1997). Some affecting factors on the success or failure of outsourcing are:

- Those outsourcing plans that are based on strategic decisions are more successful than those outsourcing plans that are undertaking immediately for resolving financial problems (Brandes et al, 1997).

- Those organizations, which establish effective and broad relations with suppliers, are more successful in outsourcing. In past, the cause of outsourcing success/failure was rooted in separating organizational core/ noncore competencies while now it is not a major factor in outsourcing success/failure and it is communication which plays the main role (Marshalla, et al, 2007).

In the present research, the impacts of bad outsourcing on five variables including organizational justice, organizational commitment, organizational identity, job security and organizational anti-citizenship

behaviors are examined. Hence, it is necessary to provide some explanations on the concepts and literature of these variables: Organizational justice is a concept paid attention by many organizational researchers (Cropanzano et al, 2001). The types of employees' perception of justice are categorized in three groups: distributive justice, procedural justice and interactional justice. Distributive justice means the equality in distributing the results and achievements (Adames, 1965); Procedural justice means equality in result allocation processes (Leventhal, 1980) and Interactional justice means equality in interpersonal behaviors (Bies and Moag, 1986). In Oxford dictionary, organizational commitment is defined as involving in a job or obligation, which limits freedom (Oxford, 2008). It means the possibility that the individual be loyal to his/her job and feels dependency to it psychologically whether it is satisfactorily or not (Rusbult and Farrel, 1983). Meanwhile, Mathieu and Zajac (1990) define it as an individual's dependency to organization. Allen and Meyer (1990) consider three aspects of organizational commitment: affective commitment (affective belonging to stay in the organization), continuance commitment (staying in the organization and being reluctant to leave it) and normative commitment, means the feeling of moral obligation to stay in organization. 
An organization's members shape and are shaped by organizational identity. Organizational members develop and express their self-concepts within the organization and the organization in turn is developed and expressed through its members' self-concepts. Organizational identity is, therefore, more than simply an answer to the question, 'Who are we?' as an organization (Gioia and Thomas, 1996); It presents, potentially, a partial answer to the question 'Who am I?' as an individual. Organizational identity conveys the idea that organizational members construct a common perception of their organization as having certain key characteristics, as being distinctive from other organizations in some respects, and as showing a degree of continuity over a period of time and in varying circumstances (Alvesson and Empson, 2008). Job security is an important issue in working life. Nowadays in industrial countries, layoff is considered as a proper guideline to mitigate the costs and improve competitiveness in business turbulence atmosphere (Sverke and Hellgren, 2002; Cascio, 1998). Recently, organizations tend to hire employees through short-term contracts and past long term, contracts are expired (Sverke et al, 2000). Job security can be defined as an individual's expectations about continuity in a job position (Davy et al, 1997), perception of a potential threat to continuity in his or her current job (Heaney et al, 1994) and overall concern about the future existence of the job (Rosenblatt and Ruvio, 1996). There are several studies on measuring job security; such measures provided by Roskies and Louis-Guerin (1990), Borg and Elizur (1992) and Mohr (2000) (Sverke and Hellgren, 2002).

The necessity of paying attention to job security becomes more important when we find that empirical studies show that job security mitigation accompanies with undesired consequences such as impaired wellbeing (Jick, 1985; Hartley et al, 1991) and complaints on health and mental distress (Ashford et al, 1989; Lim, 1996; Hartley et al, 1991). Ashford's study indicates that those people who feel no security on their future job are less satisfied than those people who are more confidence to their future job position. Researchers believe that organizational anti-citizenship behavior is employees' response to unjust punishment in workplace (Ball et al, 1994). In literature, there are many vocabularies to describe organizational anti-citizenship behavior such as aggression (Neuman and Baron, 1997), antisocial behavior (Giacalone and Greenberg, 1997), retaliation (Skarlicki and Fogler, 1997), revenge (Bies et al, 1997) and counterproductive behavior (Fox et al, 1999). According to Fox et al (1999), such behaviors are harmful for organizations through a direct impact on functioning, assets and employees. Jelinek and Ahearen (2006) believe that organizational anti-citizenship behavior among sale forces are defiance, resistance, work avoidance, aggression and revenge. To measure the aspects of organizational anti-citizenship behavior, Gholipour et al (2009) considered defiance, aggression, revenge and behaviors that damage individuals.

Generally, organizations give their employees the feeling of identity and security while outsourcing sometimes destroys the integrity of organizational culture and removes employees' role and importance instead of valuing them (Belcourt, 2006). Researchers believe that some problems of outsourcing include negative impacts on employees' morale, the risk of missing specialists, missing the jobs or employees' turnover to undesired locations and positions (Belcourt, 2006; Weidenbaum, 2005). Following to outsourcing, some employees remain and others leave the organization (Wendell, 2009). Some individuals are hired by contractors and others are downsized or leave the organization voluntarily. Such changes pose severe financial problems for organization (Ketler, 1993). Higher levels of outsourcing vacate the organization and lead into the transition of organizational knowledge and skills to contractors. Even, contractors may become aware of organizational secret information and knowledge and may become its competitor (Brandes et al, 1997). On the other hand, when outsourcing is performed intelligently, employees can retain their jobs and enjoy higher job security since outsourcing helps them to stay in market competitive conditions. Likewise, outsourcing-related cost reduction creates new marketing opportunities, creates new jobs for organization, increases the quantity of jobs and employees and/or helps the organization to import new equipment and, finally, its related training programs would be beneficial for employees (Weidenbaum, 2005).

Regarding the literature, research conceptual framework (figure 1), and research hypotheses are categorized as follow: 
- Those employees who work in bad-outsourced sectors perceive organizational justice in lower levels than those individuals who work in non-outsourced sectors.

- The organizational commitment of those employees who work in bad-outsourced sectors is lower than those ones who work in non-outsourced sectors.

- The organizational identity of those employees who work in bad-outsourced sectors is weaker than those ones who work in non-outsourced sectors.

- The job security of those employees who work in bad-outsourced sectors is lower than those ones who work in non-outsourced sectors.

- The anti-citizenship behavior of those employees who work in bad-outsourced sectors is more than those ones who work in non-outsourced sectors.

\section{Figure 1: Conceptual framework of the research}

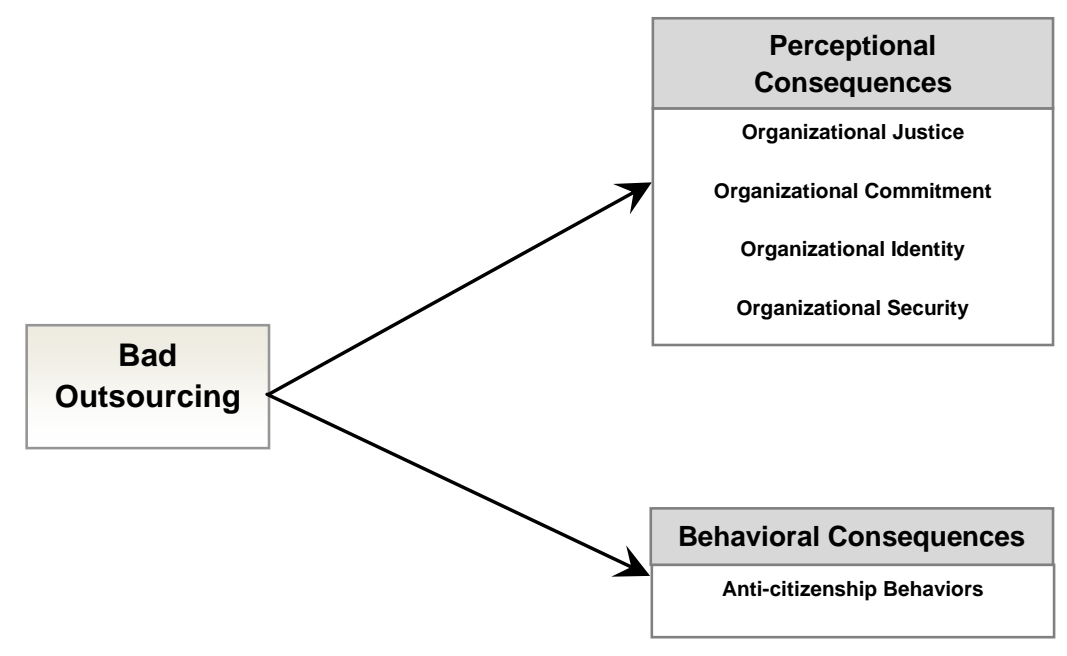

\section{Methodology}

The purpose of the present research is to compare perceptional and behavioral consequences in bad outsourced sectors at an Iranian public organization to the same consequences on employees in nonoutsourced sectors of the same organization. In this line, organizational justice, organizational commitment, organizational identity, job security and organizational anti-citizenship behavior variables are compared between two groups of its employees. Mentioned variables were examined in different organizational sectors. This research was conducted in spring and summer 2010. Questionnaire was utilized to measure mentioned variables. Developed questionnaire had 64 items with Likert's 5 scales range as well as respondents' demographical information. The first nine questions addressed to employees' perception on organizational justice. The remained questions were as follow: 24 items on organizational anti-citizenship behavior, 6 questions on organizational commitment, 5 questions on job security and 20 questions on organizational identity. To measure employees' perception of organizational justice, Kim and Leung 9-item inventory was utilized (Kim and Leung, 2007). To measure organizational commitment, Porter et al questionnaire was used (Porter et al, 1974). To examine organizational identity, researchers' self-made questionnaire was used.

To measure job security, the scale devised by Roskies and Louis-Guerin was utilized (Roskies and LouisGuerin, 1990). To study organizational anti-citizenship behaviors, Gholipour et al questionnaire, inspired by Jelinek and Ahearn research, was used with some revisions (Gholipour et al, 2009; Jelinek and Ahearn, 2006). The questionnaire was submitted to 10 experts in order to confirm its validity. As a result, minor changes were made to improve the questionnaire and to provide clearer and simpler questions. To determine its reliability, Chronbach's alpha was used and its rates were $72.4 \%, 83.5 \%, 79.8 \%, 83.1 \%$ and $72.5 \%$ for organizational justice, organizational commitment, organizational identity, job security and organizational 
anti-citizenship behavior variables respectively in a 30 subject's pretest, which indicated its high reliability. Research statistical population consists of all employees in an Iranian public organization. Based on sampling formula in an unlimited population with Disproportionate Stratified Random Sampling, 196 subjects were selected. Finally, 208 questionnaires were filled and returned.

\section{Data Analysis}

$85 \%$ of respondents were male and $15 \%$ were female. $71 \%$ were married and $29 \%$ were single. $40 \%$ had high school diploma or lower levels, $52 \%$ had associate of arts, $7 \%$ had B.A and $1 \%$ had not identified their educational level.

Hypothesis 1: Since the rate of Sig in Levene's test is 0.075 , which is greater than significance level (0.05), $\mathrm{H}_{0}$ on variance equality of populations is not rejected and we use the information of the first row of table 2 . The statistical hypothesis on mean equality test of populations is as follows:

$\mathrm{H}_{0}: \mu^{2}$ Not Outsourced $=\mu^{2}$ Outsourced

$\mathrm{H}_{1}: \mu^{2}$ Not Outsourced $\neq \mu^{2}$ Outsourced

The significance rate of mean equality test is less than 0.05 if we assume that the variances are equal so $\mathrm{H}_{0}$ is rejected and the claim on average inequality in the populations is confirmed in significance level of 0.05 . According to table 2, since both lower and upper levels are positive, we conclude that the difference between populations is greater than zero so the mean of the first population is greater than the second one. Thus, $\mathrm{H}_{1}$ is confirmed: Those employees who work in bad-outsourced sectors perceive organizational justice in lower levels than those individuals who work in non-outsourced sectors.

To study hypotheses $2,3,4$, and 5, we used similar procedure. The results of statistical tests are as follow:

Hypothesis 2: Since the rate of Sig in Levene's test is 0.025 , which is less than significance level $(0.05), \mathrm{H}_{0}$ on variance equality in populations is rejected. The significance rate of mean equality test is less than 0.05 $(0.000)$ if we assume that the variances are equal so $\mathrm{H}_{0}$ is rejected and the claim on mean inequality of populations is confirmed in significance level of 0.05 . Since both lower and upper levels are positive, we conclude that the difference between populations is greater than zero so the mean of the first population is greater than the second one. Thus, $\mathrm{H}_{2}$ is confirmed: The organizational commitment of those employees who work in bad-outsourced sectors is lower than those ones who work in non-outsourced sectors.

Hypothesis 3: Since the rate of Sig in Levene's test is 0.250 , which is greater than significance level (0.05), $\mathrm{H}_{0}$ on variance equality of populations is not rejected. The significance rate of mean equality test is less than 0.05 $(0.000)$ if we assume that the variances are equal so $\mathrm{H}_{0}$ is rejected and the claim on mean inequality of populations is confirmed in significance level of 0.05 . Since both lower and upper levels are positive, we conclude that the difference between both populations is greater than zero so the mean of the first population is greater than the second one. Thus, $\mathrm{H}_{3}$ is confirmed: The organizational identity of those employees who work in poor-outsourced sectors is weaker than those ones who work in non-outsourced sectors.

Hypothesis 4: Since the rate of Sig in Levene's test is 0.582 , which is greater than significance level $(0.05), \mathrm{H}_{0}$ on variance equality of populations is not rejected. The significance rate of mean equality test is less than 0.05 $(0.000)$ if we assume that the variances are equal so $\mathrm{H}_{0}$ is rejected and the claim on average inequality of populations is confirmed in significance level of 0.05 . Since both lower and upper levels are positive, we conclude that the difference between populations is greater than zero so the mean of the first population is greater than the second one. Thus, $\mathrm{H}_{4}$ is confirmed: The job security of those employees who work in badoutsourced sectors is lower than those ones who work in non-outsourced sectors.

Hypothesis 5: Since the rate of Sig in Levene's test is 0.470 , which is greater than significance level (0.05), $\mathrm{H}_{0}$ on variance equality of populations is not rejected. The significance rate of mean equality test is more than 0.05 (0.596) if we assume that the variances are equal so $\mathrm{H}_{0}$ is rejected and the claim on average inequality of populations is not confirmed in significance level of 0.05 . Thus, $\mathrm{H}_{5}$ is rejected and one cannot claim that anti- 
citizenship behavior of those employees who work in bad-outsourced sectors is more than those ones who work in non-outsourced sectors.

The researchers used t-test to compare two populations with each other. In table 1, the results of variance comparison between populations are initially provided and then mean equality of populations is examined.

\section{Table 1: Mean comparison test of populations}

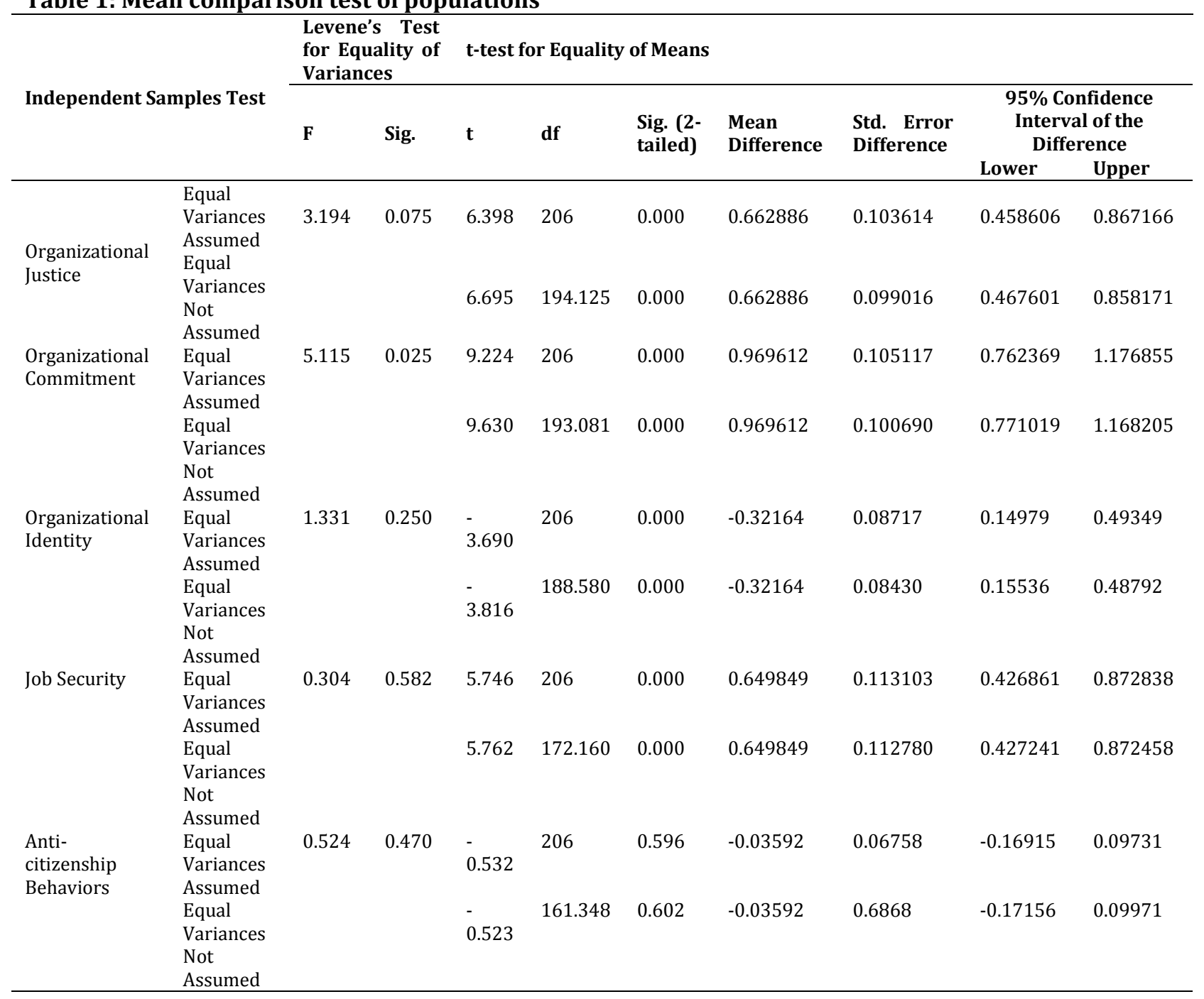

\section{Conclusion and Recommendations}

The findings indicate that bad outsourcing can lead into decrease in organizational justice, organizational commitment, organizational identity and job security. Unfortunately, two kinds of human resources are shaped in those Iranian public organizations that have outsourced part of their processes poorly: outsourced and not outsourced staff. In such unequal conditions, injustice perception and even not perceiving oppression equally may lead into employees' burnout overtime! When dealers (contractors) find that good and smart outsourcing is not happened, they try to plan a kind of modern slavery. Hence, it is vital that the government uses objective indicators and controls and monitors the performance and even internal processes of contractors regularly. Not respecting this important issue can pose irrevocable damages on domestic administrative structure and work force. However, the findings show that despite of exposing bad outsourcing and enduring serious problems, these employees have not expressed anti-citizenship behaviors. 
Through interviewing with some employees, researchers found that they are not going to express disrespectful behaviors in facing with customers despite of heavy pressures they endure. It is obvious that despite of utilizing outsourcing in recent years as a guideline to remove bureaucratic dysfunctions in Iranian worn out organizations, outsourcing is now led into new dysfunctions. The impacts of bad outsourcing is not limited to perceptional and behavioral consequences on Iranian public organizations' manpower, but it is likely accompanied with economic, social and political consequences. Hence, it seems necessary and even vital for Iranian theorists and managers to represent a new definition of outsourcing concepts and to develop the new concepts of good outsourcing and its specifications against bad outsourcing. It is suggested that future researchers pay attention to such necessity through continuing present study.

\section{References}

Adames, J. S. (1965). Inequity in social exchange, in: L. Berkowitz, Editor. Advances in experimental social psychology, 2, 267-299.

Allen, N. J. \& Meyer, J. P. (1990). The measurement and antecedents of affective, continuance, and normative commitment to the organization. Journal of Occupational Psychology, 63, 1-18.

Alvesson, M. \& Empson, L. (2008). The construction of organizational identity: Comparative case studies of consulting firms. Scand. J. Mgmt., 24, 1-16.

Ashford, S. J., Lee, C. \& Bobko, P. (1989). Content, causes, and consequences of job insecurity: A theory-based measure and substantive test. Academy of Management Journal, 4, 803-829.

Ball, G. A., Trevino, L. K. \& Jr., H. P. S. (1994). Just and unjust punishment: Influences on subordinate performance and citizenship. Academy of Management Journal, 37(2).

Belcourt, M. (2006). Outsourcing- The benefits and the risks. Human Resource Management Review, 16, 269279.

Bies R. J. \& Moag J. S. (1986). Interactional justice: communication criteria of fairness. Research on Negotiation in Organizations, 1, 43-55.

Bies, R. J., Tripp, T. M. \& Kramer, R. M. (1997). At the breaking point: cognitive and social dynamics of revenge in organizations. In R. A. Giacalone, \& J. Greenberg (Eds.), antisocial behavior in organizations, (1836). Thousand Oaks, CA: Sage.

Borg, I., \& Elizur, D. (1992). Job insecurity: Correlates, moderators and measurement. International Journal of Manpower, 13, 13-26.

Brandes, H., Lilliecreutz, J. \& Brege, S. (1997). Outsourcing - success or failure? European Journal of Purchasing \& Supply Management, 3, 63-75.

Cascio, W. F. (1998). Learning from outcomes: Financial experiences of 311 firms that have downsized. In M.K. Gowing, J.D. Kraft, \& J.C. Quick (Eds.), the new organizational reality: Downsizing, restructuring, and revitalization (21-54). Washington, DC: American Psychological Association.

Compact Oxford English Dictionary of Current English, oxford dictionaries, 2008.

Cropanzano, R., Byrne, Z. S., Bobocel, D. R. \& Rupp, D. E. (2001). Moral virtues, fairness heuristics, social entities, and other denizens of overall fairness. Journal of Vocational Behavior, 58, 164-209.

Davy, J. A., Kinicki, A. J. \& Scheck, C. L. (1997). A test of job security's direct and mediated effects on withdrawal cognitions. Journal of Organizational Behavior, 18, 323-349.

Denhardt, R. B. (1999). The future of public administration, Public administration and management, spaef.com.

Fox, S., Spector, P. E. \& Miles, D. (1999). Counterproductive work behavior (CWB) in response to job stressors and organizational justice: the moderator effect of autonomy and emotion traits. Paper presented at the annual meeting of the Society for Industrial and Organizational Psychology, Atlanta (April-May).

Gholipour, A., Saeidinejad, M. \& Zehtabi, M. (2009). The Explanation of Anti-Citizenship Behaviors in the Workplaces. International Business Research, 2 (4).

Giacalone, R. A. \& Greenberg, J. (1997). Antisocial behavior in organizations, Thousand Oaks, CA: Sage.

Gioia, D. A. \& Thomas, J. B. (1996). Identity, image, and issue interpretation: Sense making during strategic change in academia. Administrative Science Quarterly, 41(3), 370-394.

Hartley, J., Jacobson, D., Klandermans, B. \& Van-Vuuren, T. (1991). Job insecurity: Coping with jobs at risk. London: Sage. 
Heaney, C. A., Israel, B. A. \& House, J. S. (1994). Chronic job insecurity among automobile workers: Effects on job satisfaction and health. Social Science \& Medicine, 38, 1431-1437.

Jelinek, R. \& Ahearn, M. (2006). The ABCs of ACB: Unveiling a clear and present danger in the sales force. Industrial Marketing Management, 35, 457-467.

Jick, T. D. (1985). As the axe falls: Budget cuts and the experience of stress in organizations. In Beehr, T.A. \& Bhagat, R.S. (Eds.), Human stress and cognition in organizations: An integrated perspective (83-114). New York: Wiley.

Ketler, K. \& Walstrom, J. (1993). The Outsourcing Decision. International Journal of Information Management, $13,449-459$.

Kim, T. Y. \& Leung, K. (2007). Forming and reacting to overall fairness: Across-cultural comparison. Organizational Behavior and Human Decision Processes, 104, 83-95.

Leventhal, G. S. (1980). What should be done with equity theory? New approaches to the study of fairness in social relationships. In: Gergen, K., Greenberg, M. \& Willis, R. Editors, Social exchange: Advances in theory and research, Plenum Press, New York (1980), 27-55.

Lim, V. K. G. (1996). Job insecurity and its outcomes: Moderating effects of work-based and non-work based social support. Human Relations, 2, 171-194.

Marshall, D., McIvor, R. \& Lamming, R. (2007). Influences and outcomes of outsourcing: Insights from the telecommunications industry. Journal of Purchasing and Supply Management, 13 (4), 245-260.

Mathieu, J. E. \& Zajac, D. (1990). A review and meta-analysis of the antecedents, correlates, and consequences of organizational commitment. Psychological Bulletin, 108, 171-194.

Mohr, G. B. (2000). The changing significance of different stressors after the announcement of bankruptcy: A longitudinal investigation with special emphasis on job insecurity. Journal of Organizational Behavior, 21, 337-359.

Neuman, J. H., \& Baron, R. A. (1997). Aggression in the workplace. In R. Giacalone \& J. Greenberg (Eds.), Antisocial behavior in organizations (37-67). Thousand Oaks, CA: Sage.

Porter, L. W., Steers, R. M., Mowday, R. T. \& Boulian, P. V. (1974). Organizational commitment, job satisfaction, and turnover among psychiatric technicians. Journal of Applied Psychology, 59(5), 603-609.

Rosenblatt, Z. \& Ruvio, A. (1996). A test of a multidimensional model of job insecurity: The case of Israeli teachers. Journal of Organizational Behavior, 17, 587-605.

Roskies, E. \& Louis-Guerin, C. (1990). Job insecurity in managers: Antecedents and consequences. Journal of Organizational Behavior, 11, 345-359.

Rusbult, C. E. \& Farrel, D. (1983). A longitudinal test of the investment model: the impact on job satisfaction, job commitment, and turnover of variations in rewards, costs, alternatives, and investments. Journal of applied psychology, 68, 429-438.

Skarlicki, D. P. \& Folger, R. (1997). Retaliation in the workplace: The roles of distributive, procedural, and interactional justice. Journal of Applied Psychology, 82(3), 434.

Sverke, M., Gallagher, D. G. \& Hellgren, J. (2000). Alternative work arrangements: Job stress, well-being and pro-organizational attitudes among employees with different employment contracts. In Isaksson, K., Hogstedt, C., Eriksson, C. \& Theorell, T. (Eds.), Health effects of the new labor market (145-167). New York: Plenum.

Sverke, M. \& Hellgren, J. (2002). The nature of job insecurity: Understanding employment insecurity on the brink of a new millennium. Applied Psychology: An International Review, 51(1), 23-42.

Weidenbaum, M. (2005). Outsourcing: Pros and cons. Business Horizons, 48, 311-315.

Wendell, 0. J. (2009). Outsourcing in China: opportunities, challenges and lessons learned. Strategic Outsourcing: An International Journal, 2(2), 187-203. 